\title{
Alkyd based water-reducible anticorrosive paints and their antifungal potential
}

\author{
M. Martinez ${ }^{\text {a }}$, E. Gámez ${ }^{\mathrm{a}, \mathrm{b}}$, N. Bellotti ${ }^{\mathrm{a}, \mathrm{c}}, \mathrm{C}$. Deyáa $^{\mathrm{a}, \mathrm{d}, *}$ \\ ${ }^{\text {a } C I D E P I N T}$ (Centro de Investigación y Desarrollo en Tecnología de Pinturas) (CONICET-CIC-Ing. UNLP) Av. 52 e/ 121 y 122 (B1900AYB) La Plata, Argentina \\ ${ }^{\mathrm{b}}$ CONICET, Argentina \\ c CONICET, Facultad de Ciencias Naturales y Museo, UNLP, Argentina \\ ${ }^{\mathrm{d}}$ CONICET, Facultad de Ingeniería, UNLP, Argentina
}

\section{A R T I C L E I N F O}

\section{Keywords:}

Alkyd reducible paint

Zinc phosphate

Zinc aluminum phosphate

Fungi

\begin{abstract}
A B S T R A C T
Concerns about ozone layer, contamination, fossils resources and health, has banned or restricted the use of traditionally organic solvents in paints. As a consequence, new resins that employed water as main solvent are being studied. Among these resins, alkyds are the most studied one as they can also be synthesised from natural vegetable sources, making them more acceptable.

The aim of this paper was to study the anticorrosive behaviour of alkyd / polysaccharide paints containing zinc phosphate or zinc aluminum phosphate as main pigment and their performance against fungal growth. Two different PVC (pigment volume concentration) were studied. Painted panels were studied by exposition to salt spray and humidity chambers, where rusting and blistering degrees were evaluated, and by electrochemical tests (corrosion potential measurements, ionic resistances determination, linear polarization curves and polarization resistances determination).

Results showed that these type of paints can be used to protect steel and that the type of pigment and the PVC are important to the protection. Besides, good selection of both also prevents fungi growth in a high humid environment.
\end{abstract}

\section{Introduction}

Paints are one of the most useful methods to protect metals from corrosion [1-4]. They main compounds are resin (film forming material), pigments (anticorrosive pigment, prime, fillers) and solvents [5]. Alkyd resins are world-wide used as film forming material due to their ease of application and the good protection they provide to metals exposed to mildly aggressive environments $[1,5,6]$. Besides, as alkyd resins are polyesters prepared by the condensation of polyols, polybasic acids, fatty acids or triglyceride oils [7], natural sources can be used as raw materials $[8,9]$. However, alkyd resins use white spirit as solvent and, due to the concerns about the ozone layer, contamination, fossils resources and health, organic solvents traditionally used are being banned or restricted. These regulations enhanced the research and development of new water soluble resins (resins that are soluble in water) or water-reducible resins (resins having hydrophilic groups in most or all molecules) $[7,10,11]$. Modifications of resins to incorporate water as solvent can be done in the manufacturing stage by selecting water-compatible raw materials $[12,13]$ or incorporating additives such as polysaccharides [14] and silanes [15] during paint preparation.

An important problem in water-borne coatings and paints is that they are prone to microbiological degradation. This degradation is due to the fact that microorganism are able to use paint components (resin, thickeners) as carbon sources [16-18]. Biodegradation is not only important in top coats. Fungi's hyphae can penetrate the different paint layers, degrading also the inner ones [19]. In order to avoid degradation, biocides must be added also to anticorrosive paints [16].

Water-based-modified alkyd resins had been used to prepare anticorrosive coatings with good results. Dhoke prepared coatings with highly substituted methoxymethyl melamine resin as cross-linking for a water-based-alkyd resin with anticorrosive resistance properties [20]. Zhong et al. tested fluorinated acrylic-silicone modified alkyd hybrid resin (FASAR) as anticorrosive coating for steel, obtaining better results when FASAR was cross-linked with trimethylolpropane-tris-( $\beta$ - $N$-aziridinyl) propionate [21].

Phosphates, exchanged zeolites, polyaniline and ferrites are used as

\footnotetext{
* Corresponding author.

E-mail address: c.deya@cidepint.ing.unlp.edu.ar (C. Deyá).
} 
Table 1

Characteristics of the resins.

\begin{tabular}{lll}
\hline Characteristics & Alkyd resin & Polysaccharide resin \\
\hline Viscosity $(\mathrm{cp})$ & $6000 \pm 1500$ & $1200 \pm 400$ \\
Solid content (\% by weight) & $60 \pm 1$ & $44 \pm 3$ \\
$\mathrm{pH}$ & Not determined & $7 \pm 1$ \\
Density $\left(\mathrm{g} / \mathrm{cm}^{3}\right)$ & $0.92 \pm 0.01$ & $1.19 \pm 0.05$ \\
\hline
\end{tabular}

Table 2

Paints formulations.

\begin{tabular}{lllll}
\hline Compounds (\%, by volume) & $20 \mathrm{ZP}$ & $32 \mathrm{ZP}$ & $20 \mathrm{ZAP}$ & 32ZAP \\
\hline Alkyd resin & 55.8 & 46.0 & 55.8 & 46.0 \\
Polysaccharide resin & 1.1 & 3.7 & 1.1 & 3.7 \\
$\mathrm{TiO}_{2}$ & 4.1 & 7.0 & 4.1 & 7.0 \\
$\mathrm{Zinc}$ Phosphate (ZP) & 3.3 & 5.6 & - & - \\
Zinc Aluminium Phosphate (ZAP) & - & - & 3.3 & 5.6 \\
Thickener & 1.1 & 1.1 & 1.1 & 1.1 \\
Disperser & 0.3 & 0.3 & 0.3 & 0.3 \\
Butyl glycol & 5.7 & 6.3 & 5.7 & 6.3 \\
Antiflash rusting & 1.2 & 1.4 & 1.2 & 1.4 \\
Co-drier & 0.2 & 0.2 & 0.2 & 0.2 \\
Ca-drier & 1.2 & 1.0 & 1.2 & 1.2 \\
Antiskinning & 0.3 & 0.3 & 0.3 & 0.3 \\
Water & 13.4 & 16.7 & 14.1 & 17.5 \\
White spirit & 12.5 & 10.4 & 11.7 & 9.4 \\
Total & 100.0 & 100.0 & 100.0 & 100.0 \\
Pigment Volume Concentration & 20.0 & 32.0 & 20.0 & 32.0 \\
\hline
\end{tabular}

anticorrosive pigments in paints [22-26]. Phosphate-based pigments such as zinc phosphate (ZP) and zinc aluminum phosphate (ZAP) are claimed to protect steel from corrosion by phosphating and shielding the surface [27-29] being ZAP better than ZP in damage areas [30].

The aim of this research work was to study paints formulated with a water reducible mixture of synthetic alkyd and polysaccharide resins and two anticorrosive pigments: zinc phosphate (ZP) [31,32], a traditional one; and zinc aluminum phosphate (ZAP), a third generation phosphate-based pigment $[28,33,34]$. Paints were formulated with two PVC (Pigment Volume Concentration) and without biocide. Results showed that with a good selection of pigments and PVC in paint formulation anticorrosive and antifungal paint can be reached.

\section{Materials and methods}

\subsection{Raw material characterization}

The selected film forming materials were two mixtures of a medium oil alkyd (Alkipol 457/60, 60:40 resin:white spirit, Diransa, Argentina) and polysaccharide (LPR76 Lorama, 44:66 resin:water, Brazil) resins. Table 1 shows some characteristics of the commercial resins. The resins employed and the resins mixtures were characterized by FTIR spectra. The ratios of alkyd / polysaccharide resins used in the FTIR analysis were those used in the formulated paints, 55.8 / 1.1 and 46.0 / 3.7, by volume (Table 2).

\subsection{Paint formulation, preparation and application}

Besides the resins, ZP and ZAP (both provided by SNCZ, France) were used as anticorrosive pigments. The paint formula was completed with titanium dioxide as prime pigment, Co- and Ca-octoates (Casal del Rey, Argentina) as driers, thixotropic (Bentone SD-1, Elementis, Argentina), disperser and humectant (Tego 651, TEGO, Argentina) agents, butylglycol (Química Martin, Argentina) as coalescent, sodium benzoate (Anedra, Argentina) as flash rusting inhibitor and methyl ethyl ketoxime (Casal del Rey, Argentina) as antiskinning additive.

Paints were formulated considered two pigment volume concentrations (PVC) 20 and $32 \%$ being PVC defined as:

$\mathrm{PVC}=\frac{\text { Volume of pigments }}{\text { Volume of pigments }+ \text { Volume of resins }}$

The ratio alkyd / polysaccharide resins was a studied variable but titanium dioxide / anticorrosive pigment ratio was constant and the amount of anticorrosive pigment was $44.5 \%$, by volume, of the pigment formula. Paints formulations can be seen in Table 2. Taking into account the PVC and the anticorrosive pigment used, the paints were labelled as: 20ZP, 32ZP, 20ZAP and 32ZAP.

Paints were prepared in a high-speed disperser (Corradi, MTA-90 L/ 4, Vórtex, Argentina) in a $500 \mathrm{~mL}$ flask and employing a $3 \mathrm{~cm}$ blade. In a first step, the alkyd resin and white spirit were mixed at low speed (700 $\mathrm{rpm}$ ) for $3 \mathrm{~min}$. Then, the disperser and thixotrophic agents were added, at the same speed and dispersed for $3 \mathrm{~min}$. In a third step, the pigments were incorporated at low speed, one by one, and dispersed for $10 \mathrm{~min}$ at high speed (1500 rpm) before adding the other one. Afterward the speed was lowered to $700 \mathrm{rpm}$ and the polysaccharide resin, sodium benzoate

\section{Disperser and thixotropic agents}

4. Butyl glycol and antiskinning agent
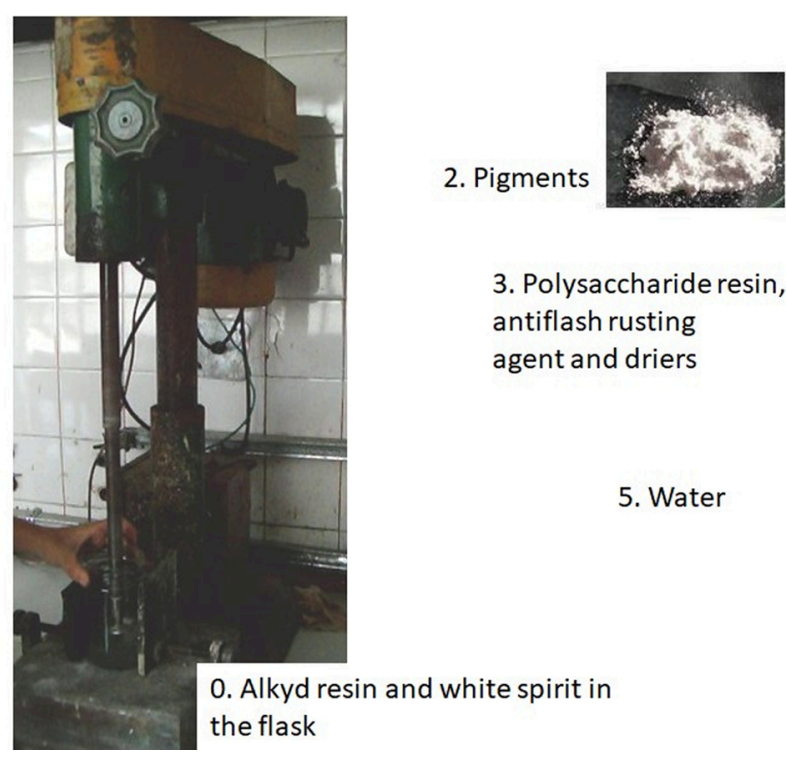

3. Polysaccharide resin, antiflash rusting agent and driers

\section{Water}

Fig. 1. Paint preparation. 
Table 3

Characteristics of the paints.

\begin{tabular}{lllll}
\hline Characterization & 20ZP & $32 \mathrm{ZP}$ & 20ZAP & 32ZAP \\
\hline Solid content & 54.5 & 59.7 & 53.6 & 57.7 \\
Viscosity (UK) & 59.0 & 62.4 & 62.5 & 61.6 \\
Grain size (Hegmann & 5 & 5 & 5 & 5 \\
$\quad$ units) & & & & \\
Hiding power ( $\mu \mathrm{m})$ & $75+75+$ & $75+75+$ & $75+75+$ & $75+75+$ \\
& 75 & 75 & 75 & 75 \\
Set-to-touch time (min) & 75 & 75 & 75 & 75 \\
Dry-through time (h) & 5 & 5 & 5 & 5 \\
\hline
\end{tabular}

(dissolved in distilled water) and driers were added and dispersed for 5 min. Finally, water, butyl glycol and antiskinning agent were incorporated and dispersed for 5 min (Fig. 1).

The use of alkyd resin together with the polysaccharide resin allowed to diminish the amount of white spirit by half volume [35,36].

The solids content was determined adding, by weight, all the solids (resins, pigments, thixotrophic and anti flash rusting agents) in $100 \mathrm{~g}$ of paint, Table 3.

The Stormer viscosity of the paints was determined by the Gardner KU-2 viscometer (USA), and adjusted to 58-63 UK in order to apply the paints by spray gun (Mota Premium, P800, Argentina).

The fineness of dispersion was evaluated employing the Hegman gage. This method uses a calibrated tapered groove varying in depth from 100 to zero $\mu \mathrm{m}$ (zero to 8 Hegman units, respectively). The liquid paint is placed in the deeper end of the channel and the excess is drawn to the shallow end with a scraper. The depth at which continuous groupings of particles or agglomerates protrude through the surface of the wet film is taken as the fineness of dispersion value [37].

The hiding power of the paints was evaluated extending the paint uniformly (employing an applicator with $75 \mu \mathrm{m}$ gap), onto a combination black-and-white board. If, after drying, the black-and-white squares are still seen, another application is done, until reaching the point of complete hiding. Results are given by the wet thickness of the films applied to hide the black-and-white board [38].

The set-to-touch time was determined lightly touching the film after awhile of application with the tip of a clean finger. Immediately, the fingertip is placed against a piece of clean, clear glass to determine when the paint does not adhere to the finger or transfer to the glass. Is considered dry-through time the time elapsed until the paint is not distorted or detached when the thumb is applied to it and rotated through a $90^{\circ}$ angle [39].

SAE 1010 steel panels were sandblasted up to Sa 21/2 degree (SIS 05 5900 ), degreased with isopropyl alcohol and painted with a spray gun. The final dried thickness was $85 \pm 7 \mu \mathrm{m}$, determined by a Schwyz, SC117-02 (Switzerland) thickness gauge. The painted panels were left at $20 \pm 2{ }^{\circ} \mathrm{C}$ and $65 \% \mathrm{RH}$ conditions for 15 days before testing.

\subsection{Assays on painted panels}

\subsubsection{Dried adhesion}

The dried adhesion of the paints to the substrate was evaluated according to ASTM D 3359 [40]. A pattern with six parallel cuts in each direction was made in the film (up to the substrate), with a cutting steel tool. Afterwards, a tape was applied over the cuts and then removed. Paint adhesion was then evaluated by comparison with illustrations and according to the removed painted area.

\subsubsection{Chambers accelerated tests}

Blistering and rusting degrees (ASTM D714 [41] and ASTM D610 [42], respectively) were evaluated as time elapsed on panels exposed to the salt spray chamber (ASTM B117 [43]). In this chamber, painted panels are exposed to an atomized neutral ( $\mathrm{pH}$ 6.5-7.2) $5 \%$ by weight sodium chloride solution. Blistering and rusting degrees are evaluated by comparison with illustrations in the ASTM standards.
In some of the panels exposed, a cut through the paint was done by a cutting steel tool in order to expose the metal directly to the salt and the creepage from the scribe was measured with a ruler $( \pm 0.1 \mathrm{~cm})$ and evaluated employing ASTM D1654 standard [44].

Other panels were placed in the humidity chamber (ASTM D2247 [45]), with $100 \%$ relative humidity and $40{ }^{\circ} \mathrm{C}$, so that condensation forms on the panels. Rusting and blistering degrees were evaluated. As no biocide was added to the paints, fungi growth was observed during exposition. These fungi were observed by stereoscopic microscope (LEICA S8APO, Germany), isolated and identified. This growth is due to the fact that fungi can use as carbon source chemical compounds from the paint and some components encourage microbial growth on the surface. Moreover, some abiotic factors influence this growth, for example, humidity and temperature.

Samples of the fungi were taken by scraping the paints and serial dilutions (1:10) were made using physiological solution [46]. Then 0.1 $\mathrm{mL}$ of solution were spreaded in Petri dishes with Agar malt extract (MEA), supplemented with streptomycin (30 mg / $100 \mathrm{~mL})$ to inhibit bacterial growth and Rose Bengal as a fungistatic (5 mg / $100 \mathrm{~mL})$. Petri dishes were incubated at $28{ }^{\circ} \mathrm{C}$ for at least $48 \mathrm{~h}$ to proceed with the isolation of the fungi by conventional microbiological techniques. The isolates were identified to the lowest possible taxon using standard taxonomic keys and bibliographic material [47,48]. Characteristics structures of the fungi were observed by Leitz wetzlab microscope (Germany).

\subsubsection{Electrochemical tests}

The cell to carry out the electrochemical tests was design by delimiting $3 \mathrm{~cm}^{2}$ area (A) employing a cylinder ( $8 \mathrm{~cm}$ high) glued to the painted surfaces. The cylinder was filled with $30 \mathrm{~mL}$ of $\mathrm{NaCl} 0.5 \mathrm{M}$. Some paint was removed from one end of the painted panels in order to get good metallic connexion.

Conductivity (Ci) measurements were done on these same cells employing a Pt ring and an ATI Orion 170 (USA) conductivity meter with high entrance impedance. The ionic resistance (Ri) was calculated as

$\mathrm{Ri}=\mathrm{Ci}^{-1} \cdot \mathrm{A}$

being A, the working painted area.

The polarization resistance (Rp) was determined from polarization curves, employing a Gamry Interface 1000 potentiostat (USA). The sweep amplitude was $\pm 20 \mathrm{mV}$ from the corrosion potential and the scan rate $0.5 \mathrm{mV} / \mathrm{s}$. Evaluation of Rp began when Ri values were lower than $10^{6} \Omega . \mathrm{cm}^{2}$, when the electrolyte has penetrated the barrier coating [49, 50].

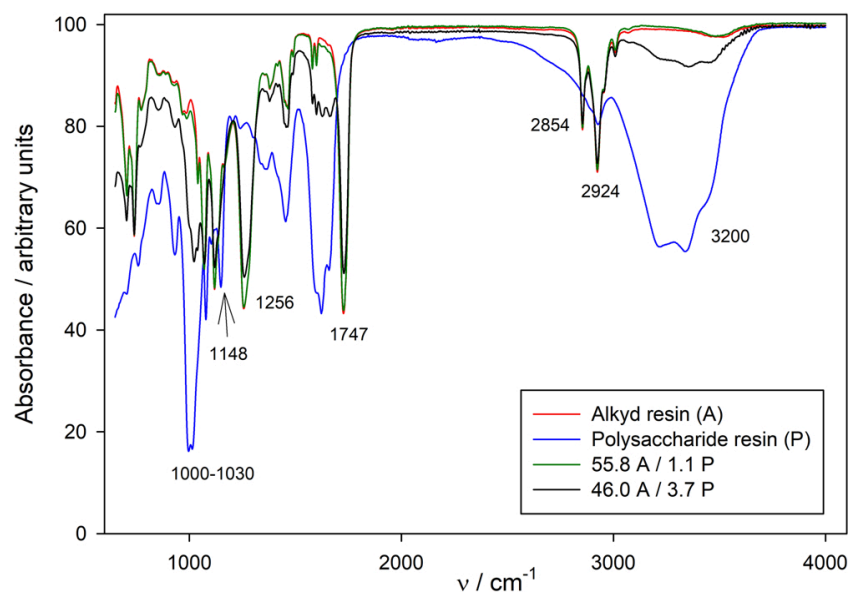

Fig. 2. FTIR spectra of the resins and their mixtures. 
Table 4

Corrosion and blistering degrees of the panels exposed to the salt spray chamber.

\begin{tabular}{|c|c|c|c|c|c|c|c|}
\hline \multirow{2}{*}{ Sample } & \multicolumn{3}{|l|}{18 days } & \multicolumn{4}{|c|}{33 days } \\
\hline & Rusting* & \multicolumn{2}{|c|}{ Blistering $^{\S}$} & \multicolumn{2}{|c|}{ Rusting* } & \multicolumn{2}{|c|}{ Blistering } \\
\hline $20 \mathrm{ZP}$ & 10 & \multicolumn{2}{|l|}{10} & \multicolumn{2}{|l|}{10} & \multicolumn{2}{|c|}{$6 \mathrm{~F}$} \\
\hline $32 \mathrm{ZP}$ & 10 & \multicolumn{2}{|l|}{$8 \mathrm{~F}$} & \multicolumn{2}{|l|}{$7 \mathrm{G}$} & \multicolumn{2}{|c|}{$4 \mathrm{MD}$} \\
\hline 20ZAP & 10 & \multicolumn{2}{|l|}{10} & \multicolumn{2}{|l|}{10} & \multicolumn{2}{|c|}{$8 \mathrm{~F}$} \\
\hline 32ZAP & 10 & \multicolumn{2}{|l|}{10} & 10 & & \multicolumn{2}{|c|}{$4 \mathrm{~F}$} \\
\hline $\begin{array}{r}\text { *Rusting } \\
\text { degree }\end{array}$ & 10 & 9 & 8 & 7 & & 6 & 5 \\
\hline rusted area / \% & $\begin{array}{l}< \\
0.01\end{array}$ & $0.01-0.03$ & $0.03-0.1$ & \multicolumn{2}{|c|}{$0.1-0.3$} & $0.3-1$ & $1-3$ \\
\hline \multicolumn{8}{|c|}{${ }^{\S}$ Blistering degree } \\
\hline Frequency & Dense, D & \multicolumn{2}{|c|}{ Medium dense, MD } & & \multicolumn{2}{|c|}{$\begin{array}{l}\text { Medium, } \\
\text { M }\end{array}$} & $\begin{array}{l}\text { Few, } \\
\text { F }\end{array}$ \\
\hline Size & 10 & \multicolumn{2}{|l|}{8} & & \multicolumn{2}{|c|}{6,4} & 2 \\
\hline Comments & $\begin{array}{l}\text { No } \\
\text { blistering }\end{array}$ & \multicolumn{3}{|c|}{$\begin{array}{l}\text { Smaller size blister easily seen } \\
\text { by unaided eye }\end{array}$} & \multicolumn{3}{|c|}{$\begin{array}{l}\text { Progressively larger } \\
\text { sizes }\end{array}$} \\
\hline
\end{tabular}

S: spot rusting - the bulk of rusting is concentrated in a few localizes areas. G: general rusting - various size spots are randomly distributed across the surface.

Table 5

Creepage of corrosion and blistering from the scribe.

\begin{tabular}{lll}
\hline Sample & 8 days & 18 days \\
\hline $20 Z P$ & 8 & 0 \\
$32 Z P$ & 7 & 0 \\
$20 Z A P$ & 9 & 7 \\
$32 Z A P$ & 8 & 2 \\
\hline
\end{tabular}

\section{Results and discussion}

\subsection{Raw material characterization}

The FTIR spectra of the resins and their mixtures can be seen in Fig. 2. In the case of the alkyd resin, the main bands of soyabean oil can be seen: 3009,2924 and $2854 \mathrm{~cm}^{-1}$ due to $\mathrm{CH}-$ stretching vibrations; 1747 and $1256 \mathrm{~cm}^{-1}$ due to $\mathrm{CO}-$ double and single bonds stretching and at $1659 \mathrm{~cm}^{-1}$ due to CC- double bond stretching [51-53]. In the case of the polysaccharides resin (P), the main bands appeared at 3200 $\mathrm{cm}^{-1}$ due to $\mathrm{OH}$ stretching (broad band), at $2923 \mathrm{~cm}^{-1}$ due to $\mathrm{CH}$ stretching. The bands at $1148 \mathrm{~cm}^{-1}$, assigned to secondary $\mathrm{OH}$ groups, and the broad one at $1000-1030 \mathrm{~cm}^{-1}$, indicate the presence of pyranose ring that is common in polysaccharides [54].

Regarding the mixtures of the resins, alkyd resin (A) bands generally prevail in the spectra. It is difficult to say if the pyranose ring is still present in the mixtures as the characteristics bands of the ring are not clearly seen, due to the low amount of resin used [54]. When the mixture corresponds to 46.0A/3.7 $\mathrm{P}$ (with higher amount of $\mathrm{P}$ resin) the broad band at $3200 \mathrm{~cm}^{-1}$, due to $\mathrm{OH}$ groups of the polysaccharide, can be seen.

\subsection{Assays on painted panels}

\subsubsection{Dried adhesion}

The dried adhesion of the paints to the substrate was qualified as $5 \mathrm{~B}$ (none of the paint was removed) in the cases of panels 20ZP, 32ZP and 20ZAP. In the other case, less than $3 \%$ of the paint was removed after the test, and the adhesion was qualified as 4B.

\subsubsection{Chambers accelerated tests}

3.2.2.1. Sal spray chamber. Rusting started to be important after 33 days, 32ZP panels exposed to the salt spray chamber. The other panels were qualified with 10 . Blisters appeared also earlier (18 days) in the case of panels 32ZP, the size of the blisters was small and the frequency few (Table 4). These results are better than those obtained in some cases with solvent alkyd paints [1,36,55] and comparable to others [56], taking into account the differences in film thickness.

The evaluation of the creepage of the corrosion from the scribe can be seen in Table 5. After 18 days in the chamber, the corrosion crept from the scribe up to more than $20 \mathrm{~mm}$ in the case of the panels $20 \mathrm{ZP}$ and 32ZP, and $2 \mathrm{~mm}$ and $12 \mathrm{~mm}$ in the cases of 20ZAP and 32ZAP, respectively. However, the scribe area was very damage as blisters and delamination appeared up to $30-60 \mathrm{~mm}$ from the scribe. In Fig. 3a the painted panels with the scribe, exposed to the salt spray chamber for 18 days, can be seen.

After 18 days, these panels were removed and unpainted by immersion in $\mathrm{NaOH} 10 \%$ at $60{ }^{\circ} \mathrm{C}$, in order to evaluate the corrosion underneath the paint. The evaluation of these panels, Fig. 3b, showed that a)
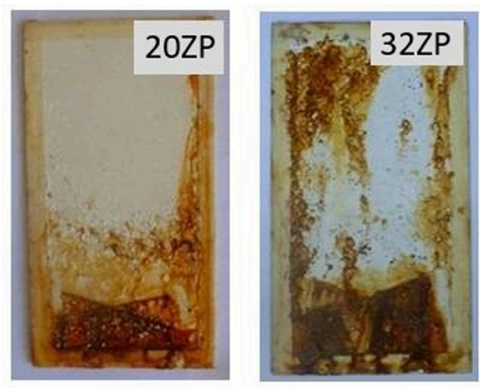

b)
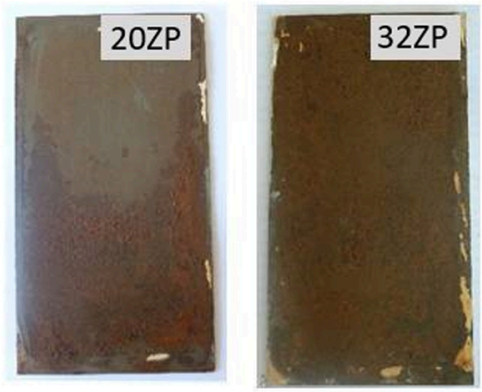
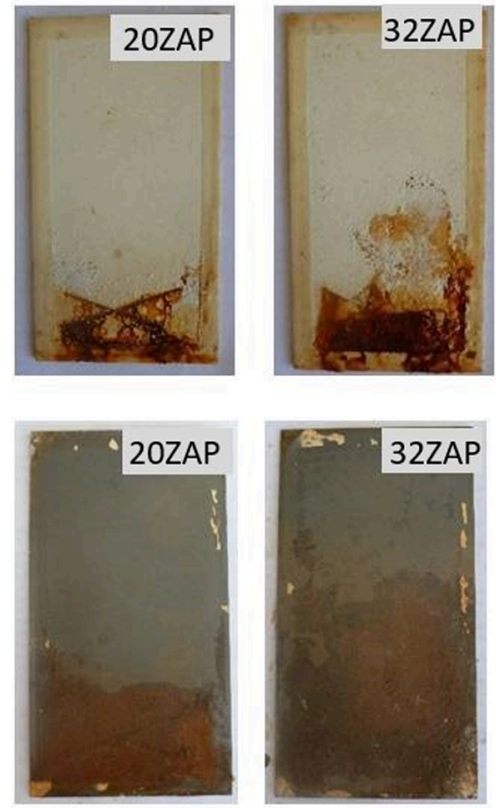

Fig. 3. Panels exposed in the salt spray chamber for 18 days: a) painted panels, b) unpainted panels. 
Table 6

Corrosion and blistering degree of the painted panels exposed to the humidity chamber.

\begin{tabular}{|c|c|c|c|c|c|c|}
\hline \multirow{2}{*}{ Samples } & \multicolumn{2}{|l|}{8 days } & \multicolumn{2}{|l|}{18 days } & \multicolumn{2}{|l|}{33 days } \\
\hline & Corrosion & Blistering & Corrosion & Blistering & Corrosion & Blistering \\
\hline $20 \mathrm{ZP}$ & 10 & $6 \mathrm{M}$ & 10 & $4 \mathrm{M}$ & $5 G$ & $2 \mathrm{M}$ \\
\hline $32 \mathrm{ZP}$ & 10 & $6 \mathrm{M}$ & $6 \mathrm{G}$ & $6 \mathrm{M}$ & $5 G$ & $6 \mathrm{M}$ \\
\hline 20ZAP & 10 & $4 \mathrm{M}$ & $8 S$ & $4 \mathrm{M}$ & $7 \mathrm{G}$ & $2 \mathrm{M}$ \\
\hline 32ZAP & 10 & $4 \mathrm{M}$ & 10 & $4 \mathrm{MD}$ & $6 \mathrm{G}$ & $4 \mathrm{D}$ \\
\hline
\end{tabular}
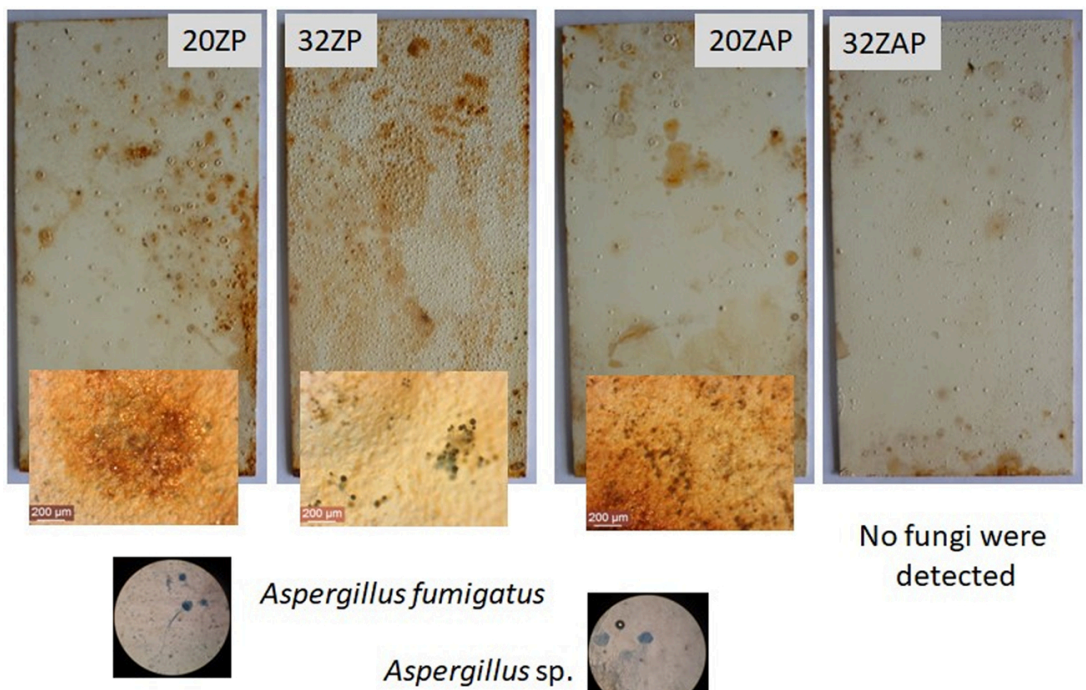

Aspergillus fumigatus

Aspergillus sp.

Fig. 4. Panels exposed to the humidity chamber after 33 days. Detail: fungi growth on the samples (80X), and stereomicroscopy photographs of the fungi.

those with ZP as anticorrosive pigment presented a large corroded area around the scribe mark, especially in the case of those protected with the paint with PVC $32 \%$. Panels painted with the paints containing ZAP, were also corroded around the scribe, but in a lesser degree. These results agree with those obtained by Mousavifard et al., being ZP less resistant than ZAP to aggressive environment in damage painted areas [57]. The important degradation around this cathodic area is due to the increased in $\mathrm{pH}$ as a consequence of the oxygen reduction reaction (cathodic delamination) [58]. The main reactions that occur are the $\mathrm{O}_{2}$ reduction and the hydrolysis of the ester unions in the alkyd resin,
[59]. It must be also taken into account that alkyd resins are susceptible of $\mathrm{HO}^{-}$degradation [60]. The unpainted area far from the scribe was only corroded in the case of panels 32ZP.

3.2.2.2. Humidity chamber. In the humidity chamber, Table 6 , blisters appeared very early due to the sensibility of the alkyd resin to this environment [60]. The blistering degree was important in all the cases but higher in 20ZP and 20ZAP panels, probably due to the presence of a greater number of carboxylic groups that are sensitive to water. Similar results were obtained by other authors employing alkyd solvent resins

$$
\mathrm{O}_{2}+2 \mathrm{H}_{2} \mathrm{O}+4 \mathrm{e}^{--\cdots--} \rightarrow 4 \mathrm{HO}-\quad \mathrm{O}_{2} \text { reduction }
$$

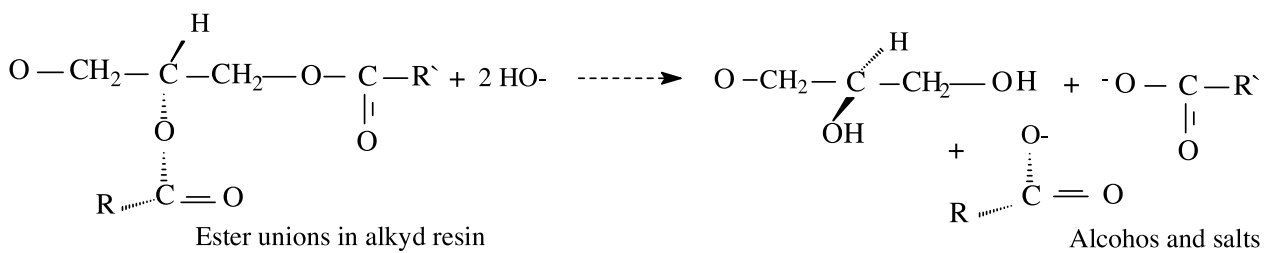

producing the degradation of the resin:

The lower degradation in the case of panels protected with paints containing ZAP indicates that the pigment is able to form a passive film on the substrate [57]. Besides, as the degradation depends on the presence of $\mathrm{HO}^{-}$, ZAP may protect the substrate by its buffer properties
$[1,56]$. Corrosion appeared after 18 days, being important in the case of panels 32ZP. In the case of 20ZAP, only few and small corrosion spots can be seen. After 33 days of exposure, corrosion was general and covered between 1 and $3 \%$ of the surface of panels 20ZP and 32ZP. 20ZAP and 32ZAP panels presented less corrosion degradation.

Through stereoscopic microscopy, fungal growth was observed on the panels exposed in the humidity chamber for 33 days except in the 


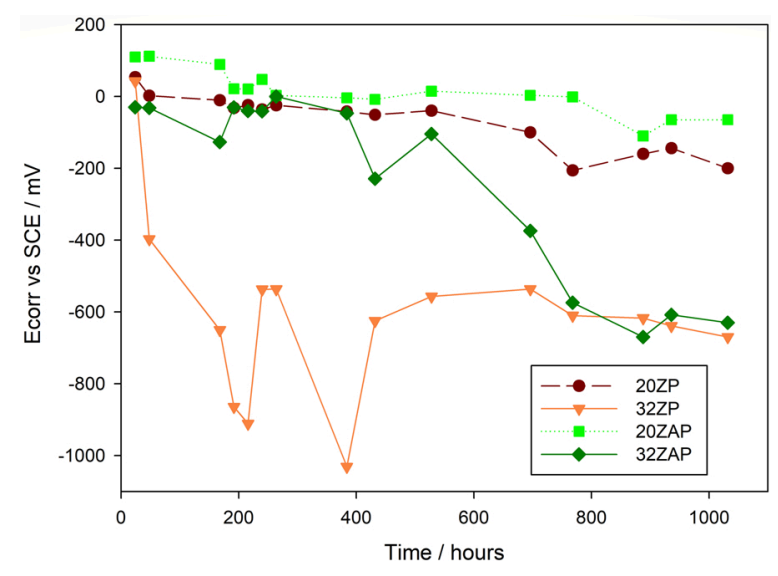

Fig. 5. Corrosion potential (Ecorr) of the painted panels.

case of panels 32ZAP (Fig. 4). In this sense, higher PVC could have brought out ZAP inhibitory activity against fungal growth by increasing the relative concentration of the solids by volume. This could produce, consequently, an increase in the exposed surface area of the solids and a more porous surface of the film. In this sense, Lin and Chen, 2017, noted that higher pore volume of non-biodegradable substrate is beneficial to prevent fungal growth [61].

After isolation and purification of the strains, it was detected that Aspergillus fumigatus (Fig. 4, detail) was the strain with a $95 \%$ frequency of appearance, followed by Aspergillus sp. (Fig. 4, detail) with $80 \%$ relative frequency. Biofilm formation is a process that occurs in stages in which the irreversible adhesion of the microorganism is fundamental. Filamentous fungi are known to highly biodeteriorate materials [62]. These fungi have an invasive growth that many times manages to break the material on which they grow and at the same time release large amount of acids that favour corrosion processes [63]. Besides, Aspergillus as is one of the most common genera associated with biodeterioration of coatings and paints [64].

\subsubsection{Electrochemical tests}

3.2.3.1. Corrosion potential. In Fig. 5, the corrosion potential values of panels protected with the different paints can be seen. In the cases of panels protected with paints with lower PVC, the corrosion potentials

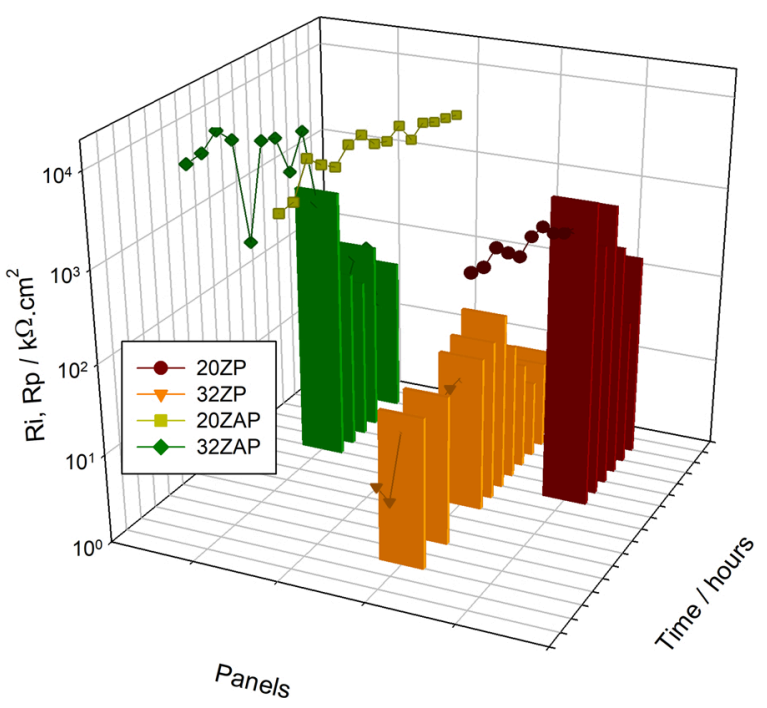

Fig. 6. Ionic resistance (Ri), as dots, and polartization resistance (Rp), as bars, of the painted panels. were depleted to more positive values along the test, being slightly more positive in the case of ZAP as anticorrosive pigment. After $700 \mathrm{~h}$, Ecorr was near $-120 \mathrm{mV}$. In the case of the panels $32 \mathrm{ZP}$ the values oscillated in an important way, probable due to changes in the cathodic / anodic surface area radio and / or to the instability of pores plug by the corrosion products [65]. However, the values were around $-600 \mathrm{mV}$ after $500 \mathrm{~h}$. At longer times, the values were stabilized [66]. In the case of panels 32ZAP, the corrosion potential values were more positive than $-200 \mathrm{mV}$ for $400 \mathrm{~h}$ but as time elapsed, the values drop, reaching -600 $\mathrm{mV}$ after $768 \mathrm{~h}$.

3.2.3.2. Ionic resistance. In Fig. 6 the ionic resistances values can be seen. It is observed that panels protected with the paints with lower PVC (panels 20ZP and 20ZAP) presented values higher than $1000 \mathrm{k} \Omega . \mathrm{cm}^{2}$ along the test. Ri values for panels 32ZAP diminished after $528 \mathrm{~h}$. Panels $32 \mathrm{ZP}$ had values lower than $10 \mathrm{k} \Omega . \mathrm{cm}^{2}$ along the tests, indicating very low barrier properties $[49,67]$. In these lasts cases, the low barrier properties were expected due to the higher PVC values of the paints [68-70].

3.2.3.3. Polarization resistance. Rp values obtained from linear polarization curves were calculated as

$R p=\frac{\Delta E}{\Delta J}$

being $\mathrm{E}$ the potential and $\mathrm{J}$ the current density. Rp values against time can be seen in Fig. 6 while selected polarization curves can be seen in Fig. 7.

Rp values could be determined after $384 \mathrm{~h}$ in the case of 32ZP, and after $528 \mathrm{~h}$ in the cases of 20ZP and 32ZAP, when the ionic resistances values were lower than $10^{3} \mathrm{k} \Omega . \mathrm{cm}^{2}$ (Fig. 6). It can also be seen that Ri values were lower than $\mathrm{Rp}$ indicating that, after the paint was penetrated by the electrolyte, the metal is protected by the anticorrosive pigment [50] as are the cases of 20ZP and 32ZAP. Rp values diminished around one order of magnitude along the 43 days of experiment. Rp values of panels 20ZAP could not be determined as Ri values were never lower than $10^{3} \mathrm{k} \Omega . \mathrm{cm}^{2}[50]$.

\section{Conclusions}

1 Alkyd resin based on soybean oil is compatible with polysaccharide resin and anticorrosive alkyd reducible coatings can be prepared mixing both resins.

2 Zinc phosphate and zinc aluminium phosphate can be incorporated in the paints.

3 Paints with PVC 20 protected better steel than paints with PVC 32, and paints with zinc aluminium phosphate behaved better than those with zinc phosphate.

4 Fungal growth was inhibited on paints with PVC 32 and zinc aluminium phosphate as anticorrosive pigment.

5 Good selection of the type of pigment and the PVC are important to prevent corrosion and fungi growth in a high humid environment.

\section{CRediT authorship contribution statement}

M. Martinez: Investigation, Writing - original draft. E. Gámez: Investigation. N. Bellotti: Methodology, Supervision. C. Deyá: Conceptualization, Methodology, Resources, Visualization, Project administration, Writing - review \& editing, Supervision, Funding acquisition.

\section{Declaration of Competing Interest}

The authors declare that they have no known competing financial interests or personal relationships that could have appeared to influence the work reported in this paper. 

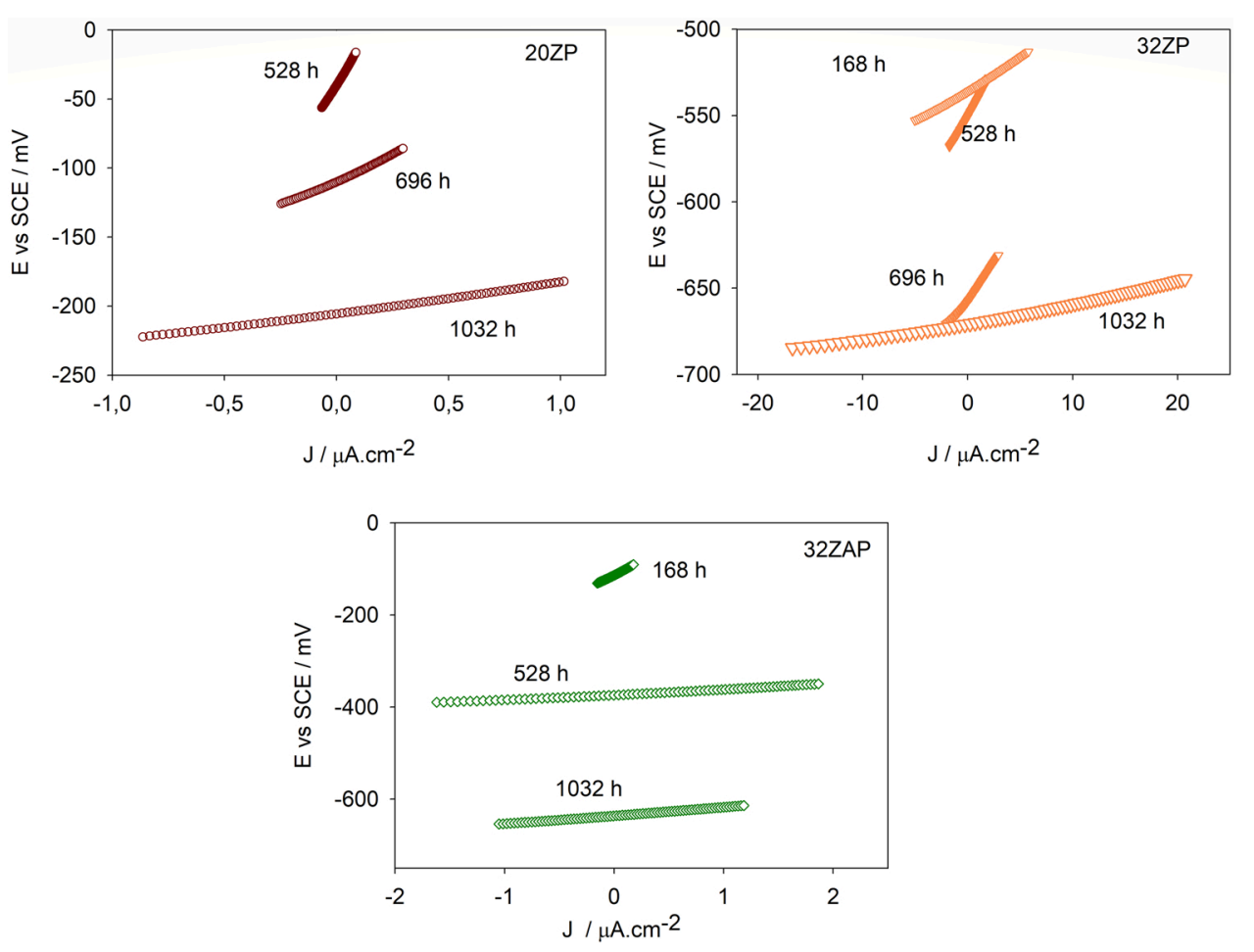

Fig. 7. Polarization curves at different immersion times.

\section{Acknowledgements}

The authors are grateful to CONICET (Consejo Nacional de Investigaciones Científicas y Técnicas), UNLP (Universidad Nacional de La Plata) and CICPBA (Comisión de Investigaciones Científicas de la Provincia de Buenos Aires) for their sponsorship to do this research. Besides, they also thank to Polidur San Luis SAIC and Lorama Chemicals Inc. for the resins.

\section{Appendix A. Supplementary data}

Supplementary material related to this article can be found, in the online version, at doi:https://doi.org/10.1016/j.porgcoat.2020.1060 69.

\section{References}

[1] O. D'Alessandro, G.J. Selmi, A.R. Di Sarli, R. Romagnoli, C. Deyá, Accelerated tests, a necessary complement of electrochemical assays to evaluate anti-corrosive coatings, J. Appl. Electrochem. 49 (2019) 811-822, https://doi.org/10.1007/ s10800-019-01324-z.

[2] T. Siva, S. Rajkumar, S. Muralidharan, S. Sathiyanarayanan, Bipolar properties of coatings to enhance the corrosion protection performance, Prog. Org. Coat. 137 (2019) 105379, https://doi.org/10.1016/j.porgcoat.2019.105379.

[3] N.M. Ahmed, M.G. Mohamed, W.M. Abd El-Gawad, The assessment of anticorrosive behavior of calcium carbonate from different sources in alkyd-based paints, Prog. Org. Coat. 128 (2019) 168-180, https://doi.org/10.1016/j. porgcoat.2018.10.012.

[4] T. da Silva Lopes, T. Lopes, D. Martins, C. Carneiro, J. Machado, A. Mendes, Accelerated aging of anticorrosive coatings: two-stage approach to the AC/DC/AC electrochemical method, Prog. Org. Coat. 138 (2020) 105365, https://doi.org/ 10.1016/j.porgcoat.2019.105365.

[5] E. Bardal, Corrosion prevention, in: B. Derby (Ed.), Corrosion and Protection, Springer, London, 2004, pp. 237-307.

[6] W.S. Araujo, I.C.P. Margarit, O.R. Mattos, F.L. Fragata, P. de Lima-Neto, Corrosion aspects of alkyd paints modified with linseed and soy oils, Electrochim. Acta 55 (2010) 6204-6211, https://doi.org/10.1016/j.electacta.2010.03.088.

[7] A. Hofland, Alkyd resins: from down and out to alive and kicking, Prog. Org. Coat. 73 (2012) 274-282, https://doi.org/10.1016/j.porgcoat.2011.01.014.

[8] N. Karak, Biopolymers for Paints and Surface Coatings, 2016, pp. 333-368, https:// doi.org/10.1016/b978-0-08-100214-8.00015-4.
[9] E. Sharmin, F. Zafar, D. Akram, M. Alam, S. Ahmad, Recent advances in vegetable oils based environment friendly coatings: a review, Ind. Crops Prod. 76 (2015) 215-229, https://doi.org/10.1016/j.indcrop.2015.06.022.

[10] M. Elrebii, A. Kamoun, S. Boufi, Waterborne hybrid alkyd-acrylic dispersion: optimization of the composition using mixture experimental designs, Prog. Org. Coat. 87 (2015) 222-231, https://doi.org/10.1016/j.porgcoat.2015.06.006.

[11] Z.W. Wicks, F.N. Jones, S.P. Pappas, D.A. Wicks, Organic Coatings_Science and Technology, 3rd ed., John Wiley \& Sons, USA, 2007 pdf $>$.

[12] J. Beetsma, Alkyd emulsion paints: properties, challenges and solutions, Pigment. Resin Technol. 27 (1998) 12-19, https://doi.org/10.1108/03699429810194401.

[13] H. Wang, R. Guo, Y. Shen, Y. Shao, G. Fei, K. Zhu, Waterborne polyaniline-graftalkyd for anticorrosion coating and comparison study with physical blend, Prog. Org. Coat. 126 (2019) 187-195, https://doi.org/10.1016/j.porgcoat.2018.10.013.

[14] K.S. Mikkonen, S. Kirjoranta, C. Xu, J. Hemming, A. Pranovich, M. Bhattarai, L. Peltonen, P. Kilpeläinen, N. Maina, M. Tenkanen, M. Lehtonen, S. Willför, Environmentally-compatible alkyd paints stabilized by wood hemicelluloses, Ind. Crops Prod. 133 (2019) 212-220, https://doi.org/10.1016/j.indcrop.2019.03.017.

[15] S. Pathan, S. Ahmad, Green and sustainable anticorrosive coating derived from waterborne linseed alkyd using organic-inorganic hybrid cross linker, Prog. Org. Coat. 122 (2018) 189-198, https://doi.org/10.1016/j.porgcoat.2018.05.026.

[16] N. Bellotti, C. Deyá, Natural products applied to antimicrobial coatings, in: R. Atta ur (Ed.), Studies in Natural Products Chemistry, Elsevier, 2019, pp. 485-508.

[17] G. Kurowski, O. Vogt, J. Ogonowski, Paint-degrading microorganisms, Czas. Tech. (2017) 81-92, https://doi.org/10.4467/2353737xct.17.211.7754.

[18] H.R. Ravikumar, S.S. Rao, C.S. Karigar, Biodegradation of paints: a current status, Indian J. Sci. Tech. 5 (2012) 1977-1987, doi:.

[19] N. Bellotti, C. Deyá, Waterborne functional paints to control biodeterioration, in: P. Zarras, M.D. Soucek, A. Tiwari (Eds.), Handbook of Waterborne Coatings, Elsevier, The Neatherlands, 2020, pp. 155-179.

[20] S.K. Dhoke, T.J.M. Sinha, P. Dutta, A.S. Khanna, Formulation and performance study of low molecular weight, alkyd-based waterborne anticorrosive coating on mild steel, Prog. Org. Coat. 62 (2008) 183-192, https://doi.org/10.1016/j. porgcoat.2007.10.008.

[21] S. Zhong, J. Li, L. Yi, Y. Cai, W. Zhou, Cross-linked waterborne alkyd hybrid resin coatings modified by fluorinated acrylate-siloxane with high waterproof and anticorrosive performance, Polym. Adv. Technol. 30 (2019) 292-303, https://doi. org/10.1002/pat. 4464 .

[22] W.M. Abd El-Gawad, N.M. Ahmed, M.M. Selim, E. Hamed, E.R. Souaya, The anticorrosive performance of cost saving zeolites, Pigment. Resin Technol. 48 (2019) 317-328, https://doi.org/10.1108/prt-09-2018-0094.

[23] F. Assassi, N. Benharrats, Synthesis, characterizations and application of polyaniline-paint as anticorrosion agent, Inorg. Nano-Metal Chem. (2020) 1-9, https://doi.org/10.1080/24701556.2020.1810707.

[24] I.S. dos Santos, L.J. de Carvalho, L.Y. Reznik, S.L.D.C. Brasil, Anti-corrosive properties of two epoxy primer systems applied to steel surfaces prepared with various mechanical abrasive treatments, J. Adhes. Sci. Technol. (2020) 1-17, https://doi.org/10.1080/01694243.2020.1767476. 
[25] M. Ziganshina, S. Stepin, S. Karandashov, V. Mendelson, Complex oxides - nontoxic pigments for anticorrosive coatings, Anti-Corrosion Methods Mater. 67 (2020) 395-405, https://doi.org/10.1108/acmm-12-2019-2222.

[26] H.S. Emira, F.F. Abdel-Mohsen, The dependence of the corrosion protection of water-borne paints on the concentration of the anticorrosive pigment, Pigment. Resin Technol. 32 (2003) 259-265, https://doi.org/10.1108/ 03699420310481604.

[27] Y. Hao, F. Liu, E.-H. Han, S. Anjum, G. Xu, The mechanism of inhibition by zinc phosphate in an epoxy coating, Corros. Sci. 69 (2013) 77-86, https://doi.org/ 10.1016/j.corsci.2012.11.025.

[28] M. Hernández, J. Genescá, J. Uruchurtu, F. Galliano, D. Landolt, Effect of an inhibitive pigment zinc-aluminum-phosphate (ZAP) on the corrosion mechanisms of steel in waterborne coatings, Prog. Org. Coat. 56 (2006) 199-206, https://doi org/10.1016/j.porgcoat.2006.05.001.

[29] Y. Shao, C. Jia, G. Meng, T. Zhang, F. Wang, The role of a zinc phosphate pigment in the corrosion of scratched epoxy-coated steel, Corros. Sci. 51 (2009) 371-379, https://doi.org/10.1016/j.corsci.2008.11.015.

[30] M.R. Heydarpour, A. Zarrabi, M.M. Attar, B. Ramezanzadeh, Studying the corrosion protection properties of an epoxy coating containing different mixtures of strontium aluminum polyphosphate (SAPP) and zinc aluminum phosphate (ZPA) pigments, Prog. Org. Coat. 77 (2014) 160-167, https://doi.org/10.1016/j. porgcoat.2013.09.003.

[31] G. Blustein, B. del Amo, R. Romagnoli, The influence of the solubility of zinc phosphate pigments on their anticorrosive behaviour, Pigment. Resin Technol. 29 (2000) 100-107, https://doi.org/10.1108/03699420010319148.

[32] M. Mahdavian, M.M. Attar, Evaluation of zinc phosphate and zinc chromate effectiveness via AC and DC methods, Prog. Org. Coat. 53 (2005) 191-194, https:// doi.org/10.1016/j.porgcoat.2005.02.007.

[33] A. Darvish, R. Naderi, M.M. Attar, The impact of pigment volume concentration on the protective performance of polyurethane coating with second generation of phosphate based anticorrosion pigment, Prog. Org. Coat. 77 (2014) 1768-1773, https://doi.org/10.1016/j.porgcoat.2014.05.025.

[34] S.N. Roselli, R. Romagnoli, C. Deyá, The anti-corrosion performance of waterborne paints in long term tests, Prog. Org. Coat. 109 (2017) 172-178, https://doi. org/10.1016/j.porgcoat.2017.04.031.

[35] G. Blustein, M.C. Deyá, R. Romagnoli, A.R. Di Sarli, B. del Amo, Improvement of anticorrosive performance of phosphate-based alkyd paints with suitable additives, J. Coat. Technol. Res. 8 (2010) 171-181, https://doi.org/10.1007/s11998-0109289-7.

[36] S. Roselli, C. Deyá, M. Revuelta, A.R. Di Sarli, R. Romagnoli, Zeolites as reservoirs for Ce(III) as passivating ions in anticorrosion paints, Corros. Rev. 36 (2018) 305-322, https://doi.org/10.1515/corrrev-2017-0090.

[37] G.D. Mills, Particle-size determinations, in: J.V. Koleske (Ed.), Paint and Coating Testing Manual, ASTM, Philadelphia, USA, 1995, pp. 305-332.

[38] L. Schaeffer, Hiding power, in: J.V. Koleske (Ed.), Paint and Coating Testing Manual, ASTM, Philadelphia, USA, 1995, pp. 485-506.

[39] T.J. Sliva, Drying time, in: J.V. Koleske (Ed.), Paint and Coating Testing Manual, ASTM, Philadelphia, USA, 1995, pp. 439-444.

[40] Standard Practice for Measuring Adhesion by Tape Test, ASTM International, West Conshohocken, PA, United States, 2009. ASTM D 3359.

[41] Standard Test Method for Evaluating Degree of Blistering of Paints, ASTM International, West Conshohocken, PA, United States, 2002. ASTM D 714.

[42] Standard Practice for Evaluating Degree of Rusting on Painted Steel Surfaces, ASTM International, West Conshohocken, PA, United States, 2001. ASTM D 610.

[43] Standard Practice for Operating Salt Spray (fog) Apparatus, ASTM International, West Conshohocken, PA, United States, 2007. ASTM B 117.

[44] Standard Test Method for Evaluation of Painted or Coated Specimens Subjected to Corrosive Environments, ASTM International, West Conshohocken, PA, United States, 2008. ASTM D1654.

[45] Standard Practice for Testing Water Resistance of Coatings in 100\% Relative Humidity, ASTM International, West Conshohocken, PA, United States, 2015 ASTM D. 2247.

[46] T. Verdier, M. Coutand, A. Bertron, C. Roques, A review of indoor microbial growth across building materials and sampling and analysis methods, Build. Environ. 80 (2014) 136-149, https://doi.org/10.1016/j.buildenv.2014.05.030.

[47] H.L. Barnett, B.B. Hunter, Illustrated Genera of Imperfect Fungi, 4th ed., APS Press The American Phytopathological Society, USA, 2003.

[48] R.A. Samson, S. Hong, S.W. Peterson, J.C. Frisvad, J. Varga, Polyphasic taxonomy of Aspergillus section Fumigati and its teleomorph Neosartorya, Stud. Mycol. 59 (2007) 147-203, https://doi.org/10.3114/sim.2007.59.14.
[49] D.J. Mills, K. Schaefer, Use of electrochemical methods to examine different surface preparation methods for organic coatings on steel, Prog. Org. Coat. 69 (2010) 193-198, https://doi.org/10.1016/j.porgcoat.2010.04.016.

[50] T. Szauer, Electrical and electrochemical resistances for the evaluation of protective nonmetallic coatings, Prog. Org. Coat. 10 (1982) 157-170, doi:.

[51] D. Goburdhun, S.B. Jhaumeer-Laulloo, R. Musruck, Evaluation of soybean oil quality during conventional frying by FTIR and some chemical indexes, Int. J. Food Sci. Nutr. 52 (2001) 31-42, https://doi.org/10.1080/09637480020027183.

[52] S. Vahur, A. Teearu, P. Peets, L. Joosu, I. Leito, ATR-FT-IR spectral collection of conservation materials in the extended region of 4000-80 $\mathrm{cm}(-)(1)$, Anal. Bioanal. Chem. 408 (2016) 3373-3379, https://doi.org/10.1007/s00216-016-9411-5.

[53] R. Gu, S. Konar, M. Sain, Preparation and characterization of sustainable polyurethane foams from soybean oils, J. Am. Oil Chem. Soc. 89 (2012) 2103-2111, https://doi.org/10.1007/s11746-012-2109-8.

[54] E. Gómez-Ordóñez, P. Rupérez, FTIR-ATR spectroscopy as a tool for polysaccharide identification in edible brown and red seaweeds, Food Hydrocoll. 25 (2011) 1514-1520, https://doi.org/10.1016/j.foodhyd.2011.02.009.

[55] A. Hadzich, S. Flores, J. Caprari, R. Romagnoli, Study of zinc tannates prepared with Tara powder (Caesalpinia spinosa) as anticorrosive pigments in alkyd paints and wash primer formulations, Prog. Org. Coat. 117 (2018) 35-46, https://doi. org/10.1016/j.porgcoat.2017.12.019.

[56] B. Chico, J. Simancas, J.M. Vega, N. Granizo, I. Díaz, D. de la Fuente, M. Morcillo, Anticorrosive behaviour of alkyd paints formulated with ion-exchange pigments, Prog. Org. Coat. 61 (2008) 283-290, https://doi.org/10.1016/j. porgcoat.2007.07.033.

[57] S.M. Mousavifard, P.M. Nouri, M.M. Attar, B. Ramezanzadeh, The effects of zinc aluminum phosphate (ZPA) and zinc aluminum polyphosphate (ZAPP) mixtures on corrosion inhibition performance of epoxy/polyamide coating, J. Ind. Eng. Chem. 19 (2013) 1031-1039, https://doi.org/10.1016/j.jiec.2012.11.027.

[58] H.J. Leidherser, W. Wang, L. Igetoft, The mechanism for the cathodic delamination of organic coatings from a metal furface, Prog. Org. Coat. 11 (1983) 19-40, doi:.

[59] M.A. Hernández, F. Galliano, D. Landolt, Mechanism of cathodic delamination control of zinc-aluminum phosphate pigment in waterborne coatings, Corros. Sci. 46 (2004) 2281-2300, https://doi.org/10.1016/j.corsci.2004.01.009.

[60] C. Hare, Trouble with paint: chemically induced degradation of coatings, part II, JPCL (2000) 63-76, doi:.

[61] C.-C. Lin, W.-Y. Chen, Effect of paint composition, nano-metal types and substrate on the improvement of biological resistance on paint finished building material, Build. Environ. 117 (2017) 49-59, https://doi.org/10.1016/j. buildenv.2017.02.013.

[62] N. Bellotti, C. Deya, Natural products applied to antimicrobial coatings. Studies in Natural Products Chemistry, 2018, pp. 485-508.

[63] N.S.I. Geweely, Evaluation of ozone for preventing fungal influenced corrosion of reinforced concrete bridges over the River Nile, Egypt, Biodegradation 22 (2011) 243-252, https://doi.org/10.1007/s10532-010-9391-7.

[64] H. Paiva de Carvalho, N. Mesquita, J. Trovão, S. Fernández Rodríguez, A. C. Pinheiro, V. Gomes, A. Alcoforado, F. Gil, A. Portugal, Fungal contamination of paintings and wooden sculptures inside the storage room of a museum: Are current norms and reference values adequate? J. Cult. Herit. 34 (2018) 268-276, https:// doi.org/10.1016/j.culher.2018.05.001.

[65] H.J. Leidheiser, Electrical and electrochemical measurements as predictions of corrosion at the metal-organic coating interface, Prog. Org. Coat. 7 (1979) 79-104, doi:.

[66] N. Rezaee, M.M. Attar, B. Ramezanzadeh, Studying corrosion performance, microstructure and adhesion properties of a room temperature zinc phosphate conversion coating containing Mn2+ on mild steel, Surf. Coat. Technol. 236 (2013) 361-367, https://doi.org/10.1016/j.surfcoat.2013.10.014.

[67] R.C. Bacon, J.J. Smith, F.M. Rugg, Electrolytic resistance in evaluating protective merit of coatings on metals, Ind. Eng. Chem. 40 (1948) 161-167, doi:.

[68] W.K. Asbeck, M. van Loo, Critical pigment volume relationships, Ind. Eng. Chem. 41 (1949) 1470-1475, doi:.

[69] D.Y. Perera, Effect of pigmentation on organic coating characteristics, Prog. Org. Coat. 50 (2004) 247-262, https://doi.org/10.1016/j.porgcoat.2004.03.002.

[70] J. Wang, H. Xu, D. Battocchi, G. Bierwagen, The determination of critical pigment volume concentration (CPVC) in organic coatings with fluorescence microscopy, Prog. Org. Coat. 77 (2014) 2147-2154, https://doi.org/10.1016/j. porgcoat.2013.12.010. 